\title{
Butting out in Canada: five down, eight to go
}

Toronto smokers forced by a new bylaw to puff outside bars and public buildings should count themselves lucky. Consider the fate of die-hard smokers across the chilly expanses of Nunavut and the Northwest Territories, who have been lighting up outdoors since May 1 , when governments introduced territory-wide bans on smoking in public places.

For anyone tracking the decades-long fight to ban smoking in public places, the last 12 months have been a relative whirlwind of activity. After years of stalling on the part of municipal and provincial governments, 5 provinces/territories and at least 75 municipalities will be 100\% smoke-free by 2005 .

Nunavut and the Northwest Territories were the first jurisdictions in Canada to pass territory- or province-wide bans. In October, Manitoba and New Brunswick will enforce provincewide bans on smoking in public buildings.

The Saskatchewan government passed anti-smoking legis\& lation on June 16, months ahead of schedule owing to public demand. Its new law, banning smoking in restaurants, bars, private clubs, bingo halls and casinos, takes effect Jan. 1.

BC, Nova Scotia and Prince Edward Island have restricted

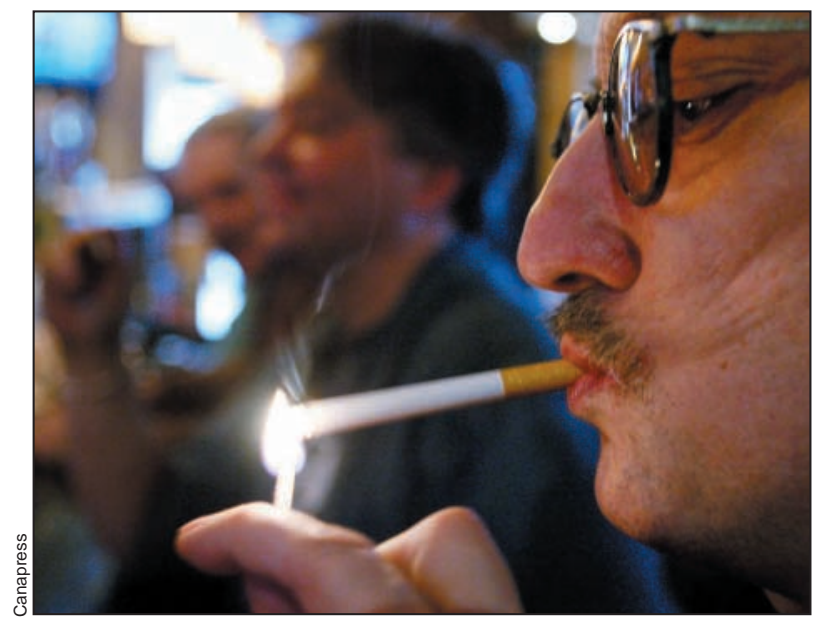

Canadians are butting out: In 1994, 29.3\% of Canadians smoked; in 2003 the rate had dropped to $22.9 \%$. smoking to specially ventilated amoking rooms in bars and restaurants.

Recently, the Ontario government announced a commitment to a province-wide smoking ban within 3 years. An official announcement is due this fall.

"This is a very significant achievement in public health," says Garfield Mahood, the executive director of the NonSmokers' Rights Association. When the first bylaws came into effect in Ontario in 1976 many said the ban in hospitals, supermarkets, retail stores and theatres was doomed. "Back then hospitals weren't even supportive," he says. "They didn't even put up their signs. That's how backward we were."

Toronto's ban puts the city in line with a patchwork of about 75 other Canadian municipalities who have adopted near absolute bans on smoking in public places.

In $\mathrm{BC}$ about 10 municipalities, including Victoria and Vancouver, have banned smoking in all bars, restaurants and workplaces outside of designated smoking rooms (DSRs).

In the Yukon, Whitehorse is phasing in a highly contentious smoking ban, which will affect bars by Jan. 2005.

Only 3 Alberta municipalities have $100 \%$ bans, however they include the province's largest cities, Calgary and Edmonton, which account for nearly $3 \mathrm{mil}-$ lion Albertans.

More than 40 Ontario municipalities have $100 \%$ smoking bans, including Toronto, Ottawa, Kingston, Guelph and Kitchener-Waterloo.

Although most provinces have some form of localized smoking bans, jurisdictional issues have restricted the passing of such laws in Quebec. Provincial legislation is in place banning smoking from all provincial government buildings and retail settings, but bars and restaurants still allow smoking as long as there is proper ventilation.

Few Nova Scotia municipalities have $100 \%$ bans, but the province does restrict smoking in bars and restaurants before 9 pm, after which unrestricted smoking is permitted. Provincial legislation also bans smoking in all provincial government buildings. Nova Scotia Premier Dr. John Hamm wants smoking rooms eliminated by 2008 .

Prince Edward Island requires bars and restaurants to provide DSRs. The rooms allow for smoking, but cannot be used for food or drink service.

Newfoundland and Labrador boasts similar laws, with smoking allowed only after 8:30 pm in restaurants with liquor licences and DSRs.

Researchers randomly surveyed 191 former smokers in southwestern Ontario to find out what factors led them to quit (Canadian Fournal of Public Health 2004;95 [3]:201-4). Nonsmoking bylaws were cited as a prime motivator by $36 \%$. The study also found that smokers who tried to quit were 3 times more successful when there was a ban in place, and found it far easier to remain abstinent.

According to Statistics Canada, the number of daily or occasional smokers has dramatically declined in the past decade, from $29.3 \%$ of people aged 12 or more in 1994 , to $22.9 \%$ in 2003. Still, one-third of people aged 20-24 smoked daily or occasionally in 2002, a rate only slightly lower than a decade ago.

However, the percentage of smokers in the grade 5 to 9 age range has declined from $7 \%$ in 1994 to just 3\% in 2002 .

About 45000 Canadians die each year from tobacco-related diseases.

Worldwide, 9 countries, including most recently Ireland, have banned public puffing (CMA7 2003;168[11]:1459). _ Bradford Mackay, Toronto 